\title{
In Memory of a Friend
}

On April 6, 1969, my friend Joe Levenson drowned in the Russian River of Northern California.

When a friend is alive, we see him only in his parts. Only when he is gone forever, do these parts come together in the unity of a full man. In reading the proofs of this book which bears Joe's imprint throughout, I sensed for the first time the nature of his quest. The history of China was an analogy to his own life, as a human being, as an intellectual, as a giver of love and friendship to many others, as a believing Jew, as a man who valued beauty and community. What he saw in China was not change with continuity, but fierce diversity which again and again reconstituted itself into unity. For Joe, China was not the triumph of Confucianism as it has been conventionally seen in the field. Nor was China the resultant institutionalization of forces, as it has appeared to me. He saw Confucianism, the doctrines of authoritarian social responsibility, as sharply opposed to the self-oriented anarchism of Taoism. These creeds and the men who upheld them did not live harmoniously together over the many centuries of Chinese history. They fought each other, sometimes bloodily. Yet somehow out of these conflicts came the spirit of syncretism. Confucianism and Taoism, and the many other conflicting currents in China, did not compromise with each other, nor did they learn to live together in peace. What made syncretism possible was the consciousness, learning, and above all humankindness of the Chinese. They realized, already in antiquity, that man has many needs, many parts. If one part overrides or is stunted, then the dialectic of yin and yang will change the constellation 
of forces, sometimes peacefully, sometimes violently. But the invisible hand of harmony always operates.

Joe began his life of thought on China with questions on the decline of Confucianism, and the substitution for it of revolutionary creeds. Then he looked at contemporary China, seeing there the reappearance of diversity ("regionalism"). When we conceived this volume on China's history, we injected into the material of history the problems of our own lives we each wrestled with. Our problems differed, yet the country and history of China are so rich that there were analogies enough for all. The spirit of syncretism preoccupied Joe more and more, as is reflected in this volume.

Like the rich country and history of China, Joe was a human being of many parts. In his life and thought, with more struggle than many of us recognized, he began to realize a syncretism. Perhaps as these volumes were coming into being, the syncretism of his own life and thought would too have developed.

Alone now, I only can offer this volume to the readers. But if we read what Joe has written over the years, we may be able to finish in thought what he has not been able to do in life.

Franz Schurmann

May, 1969 